\title{
Concentration and composition of bioaerosol emissions from intensive farms: Pig and Poultry Livestock
}

\author{
T.L. Gladding ${ }^{a}$, C.A. Rolph ${ }^{a}$, C.L. Gwyther ${ }^{a}$, R. Kinnersley ${ }^{b}$, K. Walsh ${ }^{b}$, S. Tyrrel \\ aThe Open University, Walton Hall, Milton Keynes. MK76AA. toni.gladding@open.ac.uk \\ ${ }^{b}$ The Environment Agency, Horizon House, Deanery Road, Bristol, BS1 5AH \\ 'School of Water, Energy and Environment, Cranfield University, Bedfordshire, MK43 OAL
}

\begin{abstract}
Intensive farming is widespread throughout the UK and yet the health effects of bioaerosols which may be generated by these sites are currently not well researched. A scoping study was established to measure bioaerosols emitted from intensive pig $(n=3)$ and poultry farms $(n=$ 3) during the period 2014-2015. The concentration of culturable mesophilic bacteria, Gramnegative bacteria, Staphylococcus spp., and fungi selecting for presumptive Aspergillus fumigatus were measured using single-stage impaction Andersen samplers, whilst endotoxin and $(1 \rightarrow 3)$ - $\beta$-D-glucan was undertaken using inhalable personal samplers. Particulate matter concentration was determined using an optical particulate monitor. Results showed that culturable bacteria, fungi, presumptive Staphylococcus aureus (confirmed only as Staphylococcus spp.) and endotoxin concentrations were elevated above background concentrations for distances of up to $250 \mathrm{~m}$ downwind of the source. Of all the culturable bioaerosols measured, bacteria and Staphylococcus spp. were identified as the most significant, exceeding published or proposed bioaerosol guidelines in the UK. In particular, culturable Staphylococcus spp. downwind was at least 61 times higher than background at the boundary and at least 8 times higher $70 \mathrm{~m}$ downwind on the four farms tested. This research represents a novel dataset of intensive farm emissions within the UK. Future research should exploit the use of innovative culture-independent methods such as next generation sequencing to develop deeper insights into the make-up of microbial communities emitted from intensive farming facilities and which would better inform species of interest from a public health perspective.
\end{abstract}

\section{Key Words}

Bioaerosols; Intensive Farming; Agriculture; Endotoxin; Air Sampling. 


\section{Introduction}

The use of intensive animal farming is widespread throughout the UK. There are 217,000 agricultural holdings within the UK employing approximately 474,000 people (Department of Environment, Food and Rural Affairs (Defra), 2018). There are some five million pigs and 182 million birds, 118 million of which are 'table chicken' e.g. broilers (Defra, 2018), distributed across approximately 10,900 pig farms (AHDB 2018) and 2,500 poultry farms (British Poultry Council, 2018).

Agricultural production and concentrated animal feeding operations can emit a range of pollutants to the atmosphere including odour, greenhouse gases, ammonia, volatile organic compounds and particulate matter (Defra 2018, Douglas et al., 2018, Hayes et al., 2006; Cambra-López et al., 2010; Tilman et al., 2002). Whilst some studies have investigated the effect of particulate matter on the heath of livestock workers (Andersen et al., 2004; CambraLópez et al., 2010), less is known about the exposure of the general population to bioaerosol emissions from such farming, either in the UK or elsewhere. In a systematic review to address these knowledge gaps Douglas et al., (2018) reported that a range of papers illustrated farm workers experienced respiratory and gastrointestinal problems and that negative health effects had been linked to surrounding populations and that further research was needed.

This study concentrates on bioaerosols, particulate matter from a biological origin, which are of concern as they can cause infection and an inflammatory response in the lungs, particularly in high risk groups such as the immunosuppressed or those with an existing respiratory disease (Biermann et al., 2013; Bünger et al., 2007; O'Gorman, 2011). Bioaerosols investigated here included microorganisms such as bacteria, fungi and their components endotoxin from the cell wall of Gram-negative bacteria and $(1 \rightarrow 3)-\beta-D$-glucan from the cell wall of fungi (Gutarowska et al., 2015, Swan et al., 2003, Searl, 2008).

Bioaerosols have previously been associated with farming operations such as manure spreading, where it was concluded they could pose a risk to downwind receptors (Jahne et al., 2015). Elevated concentrations of bacteria, fungi, endotoxin and antibiotic resistant bacteria have also been reported downwind of intensive swine and poultry farms (Defra, 2009; Gibbs et al., 2006; Ko et al., 2008; Schulz et al., 2012). For example, Staphylococcus aureus has previously been identified as a potential indicator organism for emissions from chicken broiler houses (Schulz et al., 2011) and occupationally on pig farms (Masclaux et al., 2013). $S$. aureus is a potential human pathogen and antibiotic resistant $S$. aureus has also previously been identified in air samples up to $150 \mathrm{~m}$ from pig feeding operations (Gibbs et al., 2006). Whilst much of the existing evidence shows that intensive farming produces bioaerosols, the distances at which concentrations return to background are unclear. A comprehensive study 
of poultry farms by Defra (2009) concluded that bioaerosols approached background values at $100 \mathrm{~m}$ downwind. However, other studies have identified drug and antibiotic resistant bacteria up to 150 m downwind of the source (Gibbs et al., 2006; Schulz et al., 2012).

It has also been identified that bioaerosol components, such as endotoxin, are present in high concentrations in air samples close to livestock farms (Schulze et al., 2006; Thorne et al., 2009; Ko et al., 2008) and that air pollutants from swine farms can cause acute respiratory symptoms in people living within 1.5 miles of swine operations (Schinasi et al., 2011). Schulze et al., (2006) reported endotoxin concentrations up to $23.2 \mathrm{EU} / \mathrm{m}^{3}$ in gardens close to intensive farms compared to $0.7 \mathrm{EU} / \mathrm{m}^{3}$ at a reference site. Endotoxin at concentrations associated with adverse health effects have since been found downwind of swine livestock operations (Thorne et al., 2009; Schinasi et al., 2011).

However, the health risk that livestock farms may pose to the general public remains uncertain. The Health Council of the Netherlands (2012) reported that "there is clear evidence that local residents can be exposed to microorganisms and substances derived from them". Outbreaks of Q-fever, caused by Coxiella burnetti, in both the Netherlands and the UK have been attributed to nearby livestock farms (van der Hoek et al., 2010; Wallensten et al., 2010). Radon et al., (2007) found an increased prevalence of wheezing with an increasing number of animal houses in the surrounding area. In contrast, a systemic review concluded that there were insufficient dose response data to draw conclusions about the impact of animal feeding operations on community health (O'Connor et al., 2010). However, Smit et al., (2012) determined there was an increased pneumonia incidence associated with the presence of poultry within $1 \mathrm{~km}$ in adults, but a later paper (Smit et al., 2014) determined there was a statistically significant negative association with farm related $\mathrm{PM}_{10}$ and all health outcomes.

For regulatory purposes an endotoxin exposure limit for the general public of $30 \mathrm{EU} / \mathrm{m}^{3}$ has been proposed in the Netherlands (Health Council of the Netherlands, 2010), but the UK has no limit. However, environmental trigger levels have been in force in the UK since 2009 for environmental concentrations of non-speciated bacteria and Aspergillus fumigatus at 1000 and $500 \mathrm{CFU} / \mathrm{m}^{3}$ downwind of waste composting (Drew et al., 2009). There is also the potential that glucan can cause airway inflammation when present above $10 \mathrm{ng} / \mathrm{m}^{3}$ (Rylander, 1997). For environmental particulate matter, $\mathrm{PM}_{10}$ has a European air quality target value of $50 \mu \mathrm{g} / \mathrm{m}^{3}$ (as a 24 hour running mean) and $\mathrm{PM}_{2.5}$ a target value of $25 \mu \mathrm{g} / \mathrm{m}^{3}$ (Defra 2012).

This study was designed as a first investigation of bioaerosols downwind from intensive farming to evaluate emissions within a regulatory context. Hence bioaerosol sampling was carried out up and downwind of three poultry and three swine farms within the UK to determine particulate matter, endotoxin, bacterial and fungal concentrations in emissions. This 
investigation was designed to measure bioaerosols using culture-dependent microbiology, and endotoxin and glucan, at all sites using the same methodology, to increase understanding of the scale and composition of viable bioaerosols associated with intensive livestock farming. The aim of this study was to improve the regulatory science evidence base needed to inform future decision-making and inform risk assessment regarding emissions from these facilities.

\section{Methods}

\section{Study design}

During 2014 and 2015 three chicken and three pig farms covered by the Environmental Permitting Regulations (2010) within the UK were selected for a pilot investigation as seen in Table 1. Sampling was undertaken on 12 separate days - each farm received two visits. Two farms were visited twice in spring 2014, and four farms twice in spring 2015.

Table 1 Summary of Farm characteristics

\begin{tabular}{|c|c|c|c|c|}
\hline $\begin{array}{l}\text { Farm } \\
\text { ID }\end{array}$ & Type & $\begin{array}{l}\text { Farm animal } \\
\text { Capacity }\end{array}$ & Ventilation & Activity \\
\hline 1 & $\begin{array}{l}\text { Chicken } \\
\text { layers }\end{array}$ & 590,000 & $\begin{array}{l}\text { Automatic temperature } \\
\text { control }\end{array}$ & $\begin{array}{l}\text { Normal running and } \\
\text { deliveries }\end{array}$ \\
\hline 2 & $\begin{array}{l}\text { Chicken } \\
\text { broilers }\end{array}$ & 205,000 & $\begin{array}{l}\text { Roof vents, } 16 \text { automatic } \\
\text { fans per shed }\end{array}$ & $\begin{array}{c}\text { Normal running chickens/ } \\
\text { mucking out }\end{array}$ \\
\hline 3 & $\begin{array}{l}\text { Chicken } \\
\text { broilers }\end{array}$ & 150,000 & Roof fans & $\begin{array}{l}\text { Normal running of } \\
\text { chickens/mucking out }\end{array}$ \\
\hline 4 & Pig & 7,000 & $\begin{array}{l}\text { Mix of automatic fans and } \\
\text { passive door and roof vents }\end{array}$ & Movement of pigs onsite \\
\hline 5 & Pig & 6,480 & Side vented fans & Normal running of pigs \\
\hline 6 & Pig & 3,510 & $\begin{array}{l}\text { Passive door and roof vents, } \\
1-2 \text { fans on older sheds }\end{array}$ & Normal running of pigs \\
\hline
\end{tabular}

Sampling was carried out at chicken farms at the peak of the cycle e.g. all animals were present in the houses and when there was activity on site, pigs were cycled continuously and therefore both represented peak intensive production. Sampling locations were selected at least 5-10 m from the nearest buildings with no overhanging trees. At each site samples were taken upwind $(10-50+m)$, onsite $(0 \mathrm{~m})$, at the downwind boundary (10-31 $\mathrm{m})$ and downwind (40-250 m) consisting of between four and five sampling points sequentially per farm per day. Downwind locations were determined by wind direction (verified by anemometer) and access considerations. All farms were surrounded by open flat farm land though this was often not in the ownership or control of the farms, hence compromises were made with distance. There were no other local sources of bioaerosols at any of the sites. 
Each farm was monitored for particulates, viable (selected) microorganisms (following the AfOR Protocol (2009), endotoxin and glucan at each sample point. Viable Staphylococcus $s p$. was carried out on four of the farms (two chicken, two pig) as an indicator of animal origin. Information on replicates is given below.

\section{Particulate sampling and enumeration}

An Osiris particulate monitor (Turnkey Instruments, Cheshire UK) was used to measure particulate concentrations. The Osiris uses a light-scattering technique to determine the concentration of airborne particles. The monitor was operated at $0.6 \mathrm{~L} / \mathrm{min}$ for at least 30 minutes at each sample location concurrently with bioaerosol sampling (each data point consists of a 30 minute run from which is calculated an average). Total suspended particulates (TSP), particulate matter with a diameter less than or equal to $10 \mu \mathrm{m}\left(\mathrm{PM}_{10}\right)$ and particulate matter with a diameter less than or equal to $2.5 \mu \mathrm{m}\left(\mathrm{PM}_{2.5}\right)$ was enumerated by this method.

\section{Weather Conditions}

Weather conditions such as cloud cover were noted manually. The Osiris was also used to log temperature, relative humidity, and wind speed and wind direction (from an inline anemometer placed at $1.8 \mathrm{~m}$ ) every minute of the sampling period.

\section{Sampling and analysis of culturable microorganisms}

Sampling of culturable microorganisms was undertaken using the impaction method with four single-stage Andersen samplers with a hemi-cylindrical baffle in accordance with the Association for Organics Recycling Protocol (AfOR, 2009). Nutrient agar (NA), MacConkey agar No. 3 (MAC) and malt extract agar (MEA) plates were prepared as outlined in the AfOR Protocol (2009) to determine concentrations of culturable bacteria, Gram-negative bacteria and fungi selecting for Aspergillus fumigatus. Mannitol salt agar (MSA) was used for the collection of Staphylococcus spp. and prepared according to the manufacturer's instructions. All media were obtained from Oxoid Ltd. (Basingstoke, UK) and supplements from Fisher Scientific (Loughborough, UK) and Sigma Aldrich (Dorset, UK). Each petri dish contained 40 $\mathrm{mL}$ of media aseptically in advance of sampling and stored at $4^{\circ} \mathrm{C}$, and were loaded on-site aseptically and connected to a vacuum pump. An inline-flow meter was used to calibrate the pump to $28.3 \mathrm{~L} / \mathrm{min}$. Plates were exposed for 2 minutes (NA, MAC and MSA) or 10 minutes (MEA). Four duplicate samples were taken at each location, with field blanks unloaded without 
exposure and control plates were left in a sealed bag onsite. All samples were returned to the laboratory for incubation on the same day as sampling. Plates were incubated for 48 hours and checked again after 3-4 days at $37{ }^{\circ} \mathrm{C}$ for bacteria and $40{ }^{\circ} \mathrm{C}$ for fungi to favour thermotolerant fungi such as $A$. fumigatus as per the AfOR (2009) protocol.

After incubation, emerging colonies on the plates were counted and positive hole correlation, (Macher, 1989), was applied where colonies exceeded 20 on a plate. Results are expressed as colony forming units per cubic metre of air sampled $\left(\mathrm{cfu} / \mathrm{m}^{3}\right)$. The limit of detection (LOD) for the Andersens were $18 \mathrm{cfu} / \mathrm{m}^{3}$ for bacteria and Staphylococcus spp. and $4 \mathrm{CFU} / \mathrm{m}^{3}$ for fungi. Each data point consists of the average of the four samples (if samples were within $25 \%$ of each other). Field blanks were used to confirm that contamination of either the media or handling of the sampler were below 2 colonies per plate.

\section{Sampling and analysis of endotoxin and $(1 \rightarrow 3)-\beta-D-g l u c a n$}

Samples for endotoxin and $(1 \rightarrow 3)-\beta-D$-glucan were collected in triplicate using pre-sterilised Institute of Occupational Medicine (IOM) personal sampling heads operated as per the AfOR (2009) protocol. IOM cassettes were loaded with $25 \mathrm{~mm} 0.8 \mu \mathrm{m}$ polycarbonate filters and operated with a pump at $2.0 \mathrm{~L} / \mathrm{min}$ for 30 minutes. Samplers were deployed in duplicate and pre-calibrated at $2.0 \mathrm{~L} / \mathrm{min}$. Field blanks were loaded but not exposed, and two control cassettes were unopened. Cassettes were returned to the laboratory and stored overnight at $4^{\circ} \mathrm{C}$. Material from the filters were then extracted into $5 \mathrm{~mL}$ of pyrogen free water (PFW) by shaking at $100 \mathrm{rpm}$ for 30 minutes. Samples were stored at $-20^{\circ}$ prior to processing.

Endotoxin and $(1 \rightarrow 3)-\beta$-D-glucan were quantified using a kinetic chromogenic Limulus amebocyte lysate (LAL) assay (ACC Associates of Cape Cod) at $37^{\circ} \mathrm{C}$ with an automated microplate reader (BioTek ELx808, Swindon, UK) as per manufacturer instructions. Kinetic readings were recorded every 30 seconds for 90 minutes. For endotoxin, five concentrations of control standard endotoxin (CSE) were prepared within the range $50-0.005$ Endotoxin Units $(E U) / m L$ using serial dilutions. LAL (Pyrotell-T) was reconstituted with glucashield buffer (to prevent glucan interference). The LOD was $0.42 \mathrm{EU} / \mathrm{m}^{3}$. For $(1 \rightarrow 3)-\beta-D$-glucan, six concentrations of glucan standard were prepared in the range $100-3.125 \mathrm{pg} / \mathrm{mL}$ using serial dilutions. Glucatell lysate reconstituted with pyrogen free water and pyrosol buffer was added to each well. The LOD was $0.26 \mathrm{ng} / \mathrm{m}^{3}$. Each data point for endotoxin and glucan were the result of the average of three filters (where analysis was replicated in triplicate for each filter). 


\section{Statistical analysis}

Statistical analysis was performed in R 3.3.0 (R Core Team 2016). To determine whether there were any differences between farm type, ANOVA was performed on log transformed downwind data followed by Tukey's pairwise comparison. The non-parametric Kruskal Wallace test was used on untransformed data to test the significance of the sampling location. This was followed by the post-hoc Dunn test of multiple comparisons using rank sums. Mean impact range was calculated as described by CEN (2015). Where results were below the limit of detection (LOD), it was planned to use half the LOD value for statistical analysis, in practice this was unnecessary for all except viable fungi.

\section{Results}

\section{Environmental Conditions}

Meteorological measurements (day averages) are presented in Table 2.

\begin{tabular}{|c|c|c|c|c|c|}
\hline $\begin{array}{c}\text { Farm } \\
\text { ID/visit }\end{array}$ & Type & Weather & $\begin{array}{l}\text { Temp } \\
\left({ }^{\circ} \mathrm{C}\right)\end{array}$ & $\begin{array}{c}\text { Relative Humidity } \\
(\%)\end{array}$ & $\begin{array}{l}\text { Wind speed (metres } \\
\text { per second) }\end{array}$ \\
\hline $1 / 1$ & $\begin{array}{l}\text { Chicken } \\
\text { layers }\end{array}$ & Sun & 10.6 & 66.7 & 0.6 \\
\hline $1 / 2$ & $\begin{array}{l}\text { Chicken } \\
\text { layers }\end{array}$ & Sun & 14.6 & 48.8 & 2.6 \\
\hline $2 / 1$ & $\begin{array}{l}\text { Chicken } \\
\text { broilers }\end{array}$ & Sun & 14.3 & 54.1 & 0.7 \\
\hline $2 / 2$ & $\begin{array}{l}\text { Chicken } \\
\text { broilers }\end{array}$ & Sun & 12.4 & 73.9 & 1.6 \\
\hline $3 / 1$ & $\begin{array}{l}\text { Chicken } \\
\text { broilers }\end{array}$ & Cloudy & 16.5 & 79.4 & 1.2 \\
\hline $3 / 1$ & $\begin{array}{l}\text { Chicken } \\
\text { broilers }\end{array}$ & Sun & 24.1 & 51.1 & 1.3 \\
\hline $4 / 1$ & Pig & Sun & 14.8 & 57.3 & 5.5 \\
\hline $4 / 2$ & Pig & Cloudy & 14.6 & 78.9 & 2.3 \\
\hline $5 / 1$ & Pig & Sun & 24.2 & 58.0 & 0.7 \\
\hline $5 / 2$ & $\mathrm{Pig}$ & Cloudy & 18.9 & 91.1 & 1.6 \\
\hline $6 / 1$ & Pig & Sun & 13.5 & 49.3 & 4.9 \\
\hline $6 / 2$ & Pig & Cloudy & 13.9 & 79.7 & 3.3 \\
\hline
\end{tabular}

Meteorological measurements showed some variation between sampling visits. Sampling was only undertaken during dry weather. Temperatures ranged from $10.6{ }^{\circ} \mathrm{C}$ to $24.2{ }^{\circ} \mathrm{C}$. Average daily wind speeds ranged from $0.6-5.5 \mathrm{~m} / \mathrm{s}$. 


\section{Bioaerosols}

Bioaerosols were detected in all sites as seen in Figure 1. Of the culturable bioaerosols bacteria and Staphylococcus spp. were identified as the most significant, exceeding published or proposed bioaerosol guidelines (1000 cfu/ $\mathrm{m}^{3}$ proposed by Drew et al., 2009) and having higher concentrations downwind compared to upwind. Staphylococcus spp. were found in significant culturable concentrations (up to $1.4 \times 10^{4} \mathrm{cfu} / \mathrm{m}^{3}$ ) at farm boundaries and at $70 \mathrm{~m}$ downwind (up to $1.9 \times 10^{3} \mathrm{cfu} / \mathrm{m}^{3}$ ). General fungi, presumptive Gram-negative bacteria and $A$. fumigatus were all detected across all sites but at low concentrations and mostly with no significant increase in concentration in downwind compared to upwind samples (Figure 1). Broadly the source impact range was in most cases between -50m (upwind) and 50-100m (downwind). The incidence of occasional high concentrations upwind of source may suggest that upwind sampling points were too close to source and subject to a source influence, as other sources were not seen within $250 \mathrm{~m}$. 

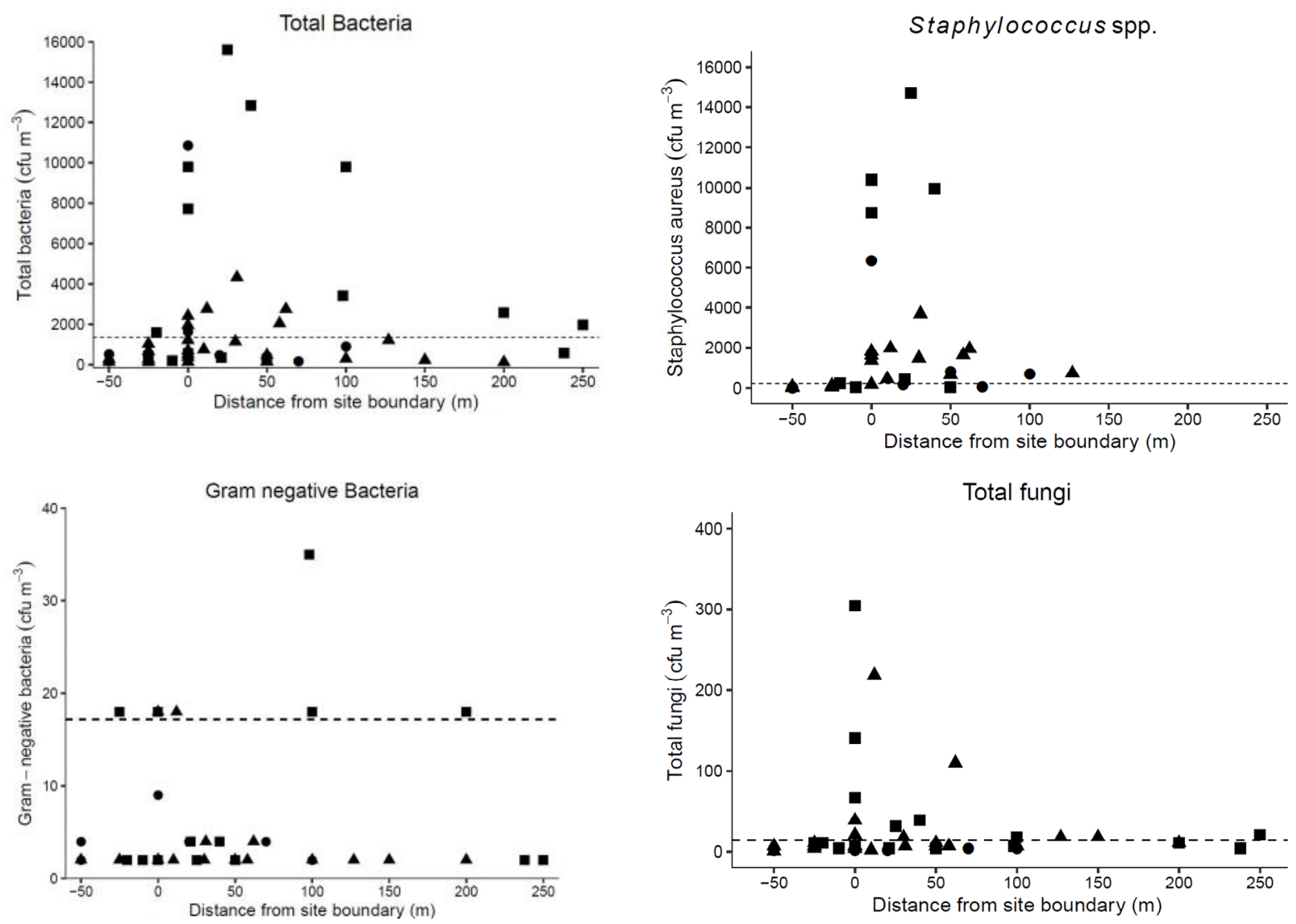

A. fumigatus

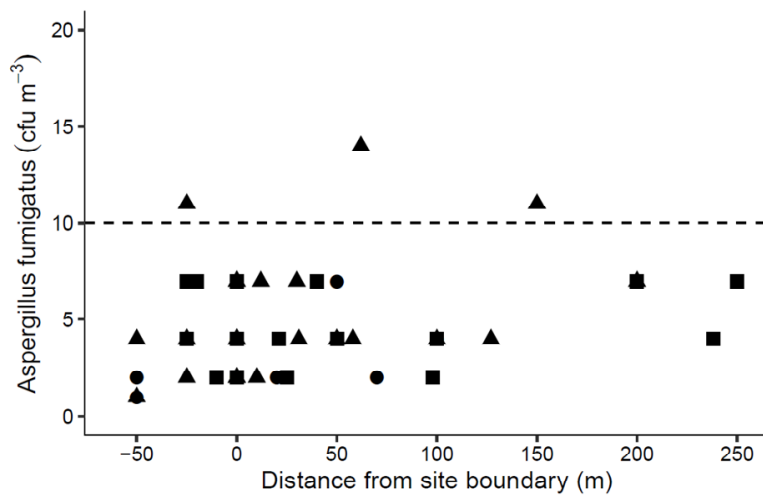

- Broilers

- Layers

$\Delta$ Swine

Figure 1 Culturable bioaerosol concentrations from different types of farm. Dashed lines indicate mean upwind concentration plus 2 standard deviations. Note Staphylococcus spp. are results from four farms, the remaining graphs are results from all six farms.

The bioaerosol components and particulates tested are displayed in Figure 2 (average of replicates). Endotoxin concentrations exceeded proposed guidelines (30 EU/m ${ }^{3}$ (Health Council of the Netherlands, 2010) in both upwind and downwind samples up to $62 \mathrm{~m}$ from the source. Values for total suspended particulates (TSP) were below $250 \mu \mathrm{g} / \mathrm{m}^{3}$ with the exception of one sampling location at a layer farm where values averaged $379 \mu \mathrm{g} / \mathrm{m}^{3}$ at source. There was no significant difference between farm type or between sampling location for any of the particulate measurements taken ( $p>0.05)$. 

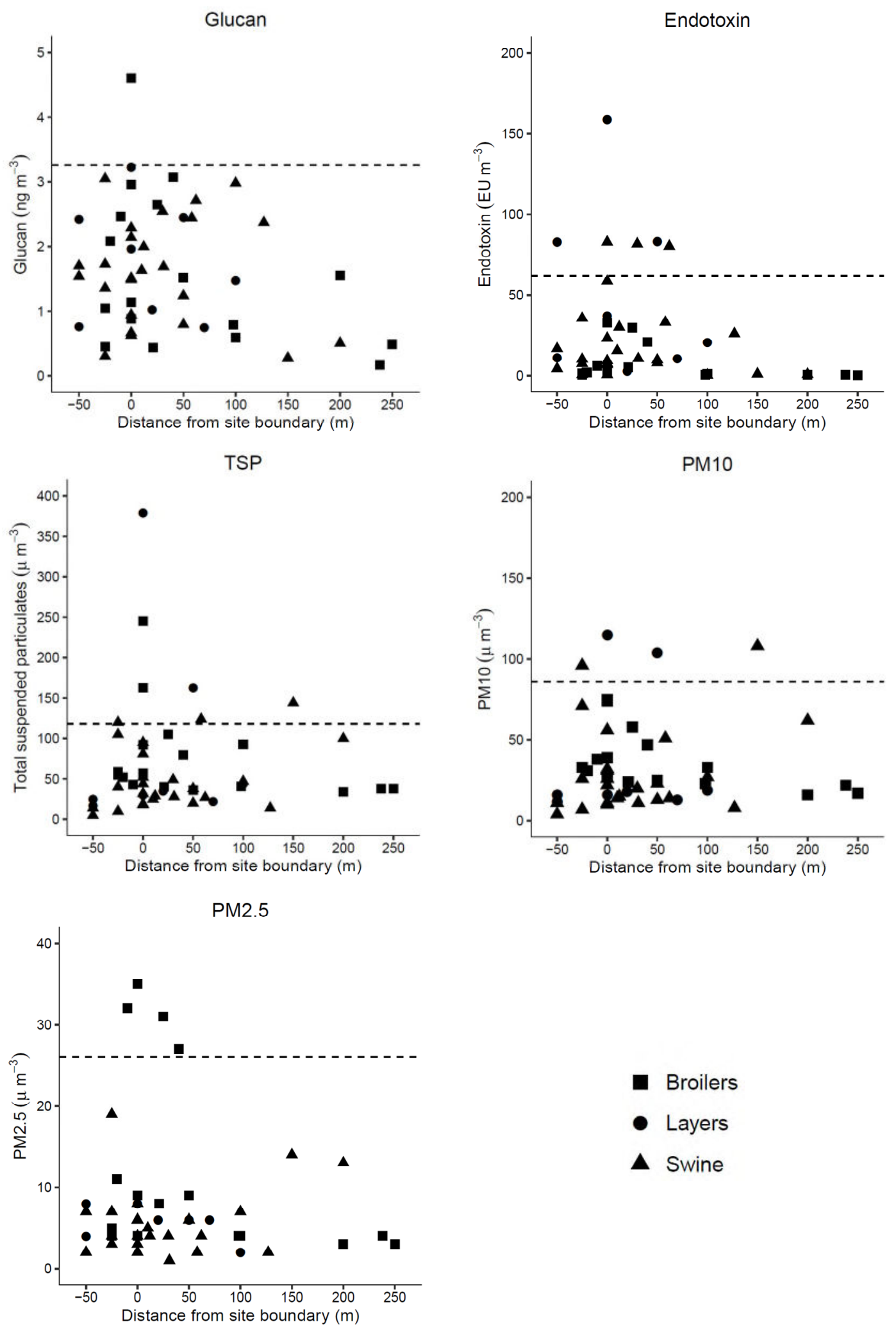

- Broilers

- Layers

$\Delta$ Swine

Figure 2 Bioaerosol components and particulate concentrations from different types of farm. Dashed lines indicate mean upwind concentration plus 2 standard deviations

Bioaerosols showed a clear reduction in concentration with location. Generally upwind samples had relatively low concentrations of bioaerosol and were significantly different from 
source and downwind samples for bacteria and Staphylococcus spp. $(P<0.05)$ illustrated in Figure 3. However there was no significant difference in endotoxin across the different locations $(P>0.05)$. The source type had a small impact on the amount of bioaerosol emitted. Significantly less endotoxin was measured from the broilers $\left(8.61 \mathrm{EU} / \mathrm{m}^{3}\right)$ compared to layers $\left(52.18 \mathrm{EU} / \mathrm{m}^{3}\right)$ but there was no difference for swine compared to broilers or Staphylococcus spp. (Table 3). Whilst broiler emissions resulted in apparent higher concentrations of bacteria, there was no significant difference when compared to the other farm types.

Table 3 Mean bioaerosols concentration by location and source type. Values in parenthesis indicate concentration range and letters indicate groups of statistical similarity.

\begin{tabular}{|c|c|c|c|c|c|c|}
\hline & \multicolumn{3}{|c|}{ Sampling Location } & \multicolumn{3}{|c|}{ Source Type (Downwind data) } \\
\hline & Upwind & Source & Downwind* & Layers & Broilers & Swine \\
\hline Bacteria $\left(\mathrm{CFU} / \mathrm{m}^{3}\right)$ & $\begin{array}{c}479(141- \\
1608)\end{array}$ & $\begin{array}{l}3,674(141 \\
-10,870)^{a}\end{array}$ & $\begin{array}{c}2631(124- \\
15,600)^{\mathrm{a}}\end{array}$ & $\begin{array}{l}2,421(177 \\
-10,870)^{d}\end{array}$ & $\begin{array}{l}5,795(265 \\
-15,601)^{\mathrm{de}}\end{array}$ & $\begin{array}{c}1,246(124 \\
-4,329)^{\mathrm{e}}\end{array}$ \\
\hline $\begin{array}{l}\text { Staphylococcus } \\
\text { Spp. (CFU/m³) }\end{array}$ & $\begin{array}{c}75(18- \\
230)\end{array}$ & $\begin{array}{c}3995(177- \\
10,390)^{\mathrm{b}}\end{array}$ & $\begin{array}{c}2471(35- \\
14,700)^{\mathrm{b}}\end{array}$ & $\begin{array}{c}1,608(71- \\
6,343)^{f}\end{array}$ & $\begin{array}{c}7,374(35- \\
14,700)^{f}\end{array}$ & $\begin{array}{l}1,468(177 \\
-3,693)^{f}\end{array}$ \\
\hline Endotoxin $\left(\mathrm{EU} / \mathrm{m}^{3}\right)$ & $\begin{array}{c}14.89(0.60 \\
-82.71)^{c}\end{array}$ & $\begin{array}{c}33.03 \\
(0.220- \\
158.70)^{c}\end{array}$ & $\begin{array}{c}19.71(0.22- \\
82.97)^{\mathrm{c}}\end{array}$ & $\begin{array}{l}52.18(3.03 \\
-158.70)^{9}\end{array}$ & $\begin{array}{c}8.61(0.22- \\
32.84)^{\mathrm{h}}\end{array}$ & $\begin{array}{c}25.58 \\
(0.45- \\
82.70)^{g h}\end{array}$ \\
\hline
\end{tabular}

${ }^{*}$ From on-site to furthest sampling point pooled

All field blanks and controls were clear of contamination and recorded concentrations below the limit of detection.

\section{Discussion}

This is the first data collection of bioaerosols from intensive pig and poultry sites utilising a standardised sampling approach (AfOR Protocol 2009), which has simultaneously sampled for and enumerated culturable microorganisms, endotoxin, and $(1 \rightarrow 3)-\beta-D$-glucan within the UK. This is a unique dataset regarding emissions from intensive farming, and in a recent systematic review it was reported that studies of exposure downwind from intensive farming were much rarer than occupational in a ratio of 1:21 (Douglas et al., 2018).

This research measured the distance bioaerosols travelled from source before returning to background. Previous work in the UK (Defra 2009) examined culturable bioaerosols, endotoxin and particulates at poultry houses and determined that these bioaerosols were reduced to background within $100 \mathrm{~m}$ from source. However, Gibbs et al., (2006) found that concentrations were significantly higher than upwind up to $150 \mathrm{~m}$ from source. Our study 
265 found that particulate concentrations were elevated close to source at both chicken and pig 266 farms but returned to background concentrations within $150 \mathrm{~m}$ from source (Figure 2). However, some concentrations of bacteria and Staphylococcus spp. remained elevated above background concentrations potentially to $250 \mathrm{~m}$. Smit et al., (2014) modelled health outcomes based on $\mathrm{PM}_{10}$, but in this study it was not clear whether particulate matter was a good predictor of bioaerosol concentrations downwind. Douglas et al., (2018) report that farms are required to carry out a bioaerosol risk assessment if sensitive receptors (such as people living or working nearby) are within $100 \mathrm{~m}$, which contrasts to the requirement at waste composting sites which is $250 \mathrm{~m}$. This study indicates that distances travelled by organisms such as Staphylococcus spp. were found to be up to $250 \mathrm{~m}$, hence farms should be required to carry out an assessment to match that currently required of waste composting, though perhaps targeted at bacteria, which is discussed further below.

In terms of the composition of the bioaerosols, although there was significant between-site (of different farm types) and within-site (of the same farm types) variability, there was evidence that culturable bacteria concentrations can be significantly elevated at both chicken and pig farms. However, culturable fungi, particularly A. fumigatus, are much lower and are therefore not likely to pose a significant concern or be a useful indicator organism in these circumstances. Ko, et al., (2008) demonstrated bacteria had a stronger downwind signature in relation to upwind concentrations compared to fungi at farm sites and Defra (2009) found that the emission profile of bacteria was consistently higher than for fungi. This finding contrasts with the findings of studies at biowaste sites where fungi are consistently detected in higher concentrations (Swan, et al., 2003, Searl, 2008, Gutarowska, et al., 2015) and indicates a different emission spectrum at intensive farms compared to organic waste processing facilities.

Staphylococcus species were elevated at source on site on all four farms studied, in particular on broiler and layer chicken sites with concentrations exceeding $1.4 \times 10^{4} \mathrm{cfu} / \mathrm{m}^{3}$ in individual replicates. The highest upwind/background samples on farms showed Staphylococcus spp. at concentrations of $230 \mathrm{cfu} / \mathrm{m}^{3}$ but more often below $100 \mathrm{cfu} / \mathrm{m}^{3}$, i.e. downwind were 61 times higher than background at the boundary and 8 times higher $70 \mathrm{~m}$ downwind on the four farms tested. It is also possible the upwind samples were on occasion contaminated by the farm site due to restrictions in upwind sampling distance, hence the differences may in fact have been more marked compared to background. The vast majority of colonies were presumptive Staphylococcus aureus (as identified by colony colour on MSA) on selective agar. Schulz et al., (2012) also found significant differences in the amount of Staphylococcus species upwind compared to downwind (as MRSA) from farms. 
Previous work, and this research, shows that culturable Staphylococcus species appear to be a reliable indicator of animal house emissions at both chicken and pig farms. Since there is not an equivalent Staphylococcus species dataset for biowaste facilities in England, as they are not considered indicator organisms in the AfOR (2009) protocol, it is not known if Staphylococcus species are also indicative of emissions from such sites. It is a limitation of this study that confirmation was not carried out on the presumptive culturable Staphylococcus spp. found, and future studies require further microbiological analysis to confirm Staphylococcus species.

In addition to the health concerns a pathogen such as Staphylococcus aureus poses, it also has the potential to be a source of antibiotic resistance which could contribute to the presence of such organisms within the environment around farms. Previous work identified that Staphylococcus species isolated both on pig farms (Masclaux et al., 2013) and downwind of farms (Schulz, et al., 2012) were antibiotic resistant strains such as MRSA. Future work on UK farms should consider this possibility.

For other organisms, culturable Gram-negative bacteria were around the limit of detection around all sites. Generally it appears that culturable Gram-negatives remain low in other settings such as waste management (Gladding and Gwyther 2017) and is not included as a parameter in the replacement to the AfOR Protocol (2009), known as M9 (Environment Agency 2017), within the UK. However, concerns have grown over recent years because of the emergence of antibiotic resistant Enterobacteriacaea among livestock (Seiffert et al., 2013), and further work should perhaps be targeted on these as additional indicators.

Endotoxin appears to be elevated downwind in this study at concentrations exceeding the suggested environmental limit of $30 \mathrm{EU} / \mathrm{m}^{3}$ at distances of up to $62 \mathrm{~m}$, even though culturable Gram-negative bacteria were low. Schulz, et al., (2006) found elevated concentrations of endotoxin in the vicinity of intensive farming, though with some spatial variability. Defra (2009) also reported a significant emission profile of endotoxin from poultry farms as did Thorne, et al., (2009) from swine farming. In contrast, the concentrations of $(1 \rightarrow 3)-\beta-D-g l u c a n$ found in this study are low, which corresponds to the lower signature of culturable fungi. There is no comparable dataset on $(1 \rightarrow 3)$ - $\beta$-D-glucan emissions from intensive farming in the literature.

Further work is needed regarding dispersion from farms incorporating boundary and distance sampling. The downwind distances sampled in this study were limited by practicalities of access at the sites studied. Future studies should aim to capture distances further downwind, simultaneously to upwind, to assess the extent of the dispersion decay curves and the point at which they approach background concentrations, although it is acknowledged access is often difficult. Finally, this study was limited to targeted viable 
microorganisms, but initial scoping work on the non-viable component (not reported here due to limitations in methodological design) indicate that the diversity of species being emitted from intensive pig and poultry farms warrants further investigation.

\section{Conclusions}

Intensive pig and poultry farming has a measurable impact on the bioaerosols concentration downwind of facilities. Viable cultivation revealed that bacteria, culturable fungi, and Staphylococcus spp., and endotoxin, were elevated above background levels at source and for varying distances of up to $250 \mathrm{~m}$ downwind. In conclusion, this study found that from a regulatory perspective, the suite of indicator organisms used to monitor biowaste sites is not directly transferable to intensive farms. There is also evidence to suggest that bioaerosol concentrations remain elevated for a greater distance downwind of animal houses than was found in a previous UK study but commensurate with that found at biowaste facilities, indicating that the requirement to carry out a risk assessment downwind should be harmonised between farms and waste sites. Further monitoring work should be targeted at particle size, and distribution and dispersion. Future research should also exploit more innovative cultureindependent technology such as next generation sequencing to provide a more comprehensive understanding of the species of interest from a public health perspective to inform new targets for cultivation.

\section{References}

AfOR (2009) A standardised protocol for the monitoring of bioaerosols at open composting facilities. Northamptonshire. Edited $T$ Gladding. Available at: http://www.organicsrecycling.org.uk/page.php?article=1750\&name=Standardised+Protocol+for+Monitoring+Bioae rosols (Accessed: 5/12/16).

AHDB (2018) Pig holdings in the UK. Agricultural and Horticultural Development Board. http://pork.ahdb.org.uk/prices-stats/industry-structure/pig-holdings-in-the-uk/ (accessed 30/10/18)

Andersen C. I., Von Essen S. G., Smith L. M., Spencer J., Jolie R., Donham, K. J. (2004) Respiratory symptoms and airway obstruction in swine veterinarians: A persistent problem. American Journal of Industrial Medicine, 46(4), pp. 386-392

Biermann J., Merk H. F., Wehrmann W., Klimek L., Wasem J. (2013) Allergic disorders of the respiratory tract - Findings from a large patient sample in the German statutory health insurance system. Allergo Journal, 22(6), pp. 366-373 
Bünger J., Schappler-Scheele B., Hilgers R., Hallier, E. (2007) A 5-year follow-up study on respiratory disorders and lung function in workers exposed to organic dust from composting plants. Int Arch Occup Environ Health, 80, 306-312

British Poultry Council (2018) About the British Poultry Council. https://www.britishpoultry.org.uk/about$\mathrm{bpc} /($ accessed 30/10/18)

Cambra-López M., Aarnink A. J. a, Zhao Y., Calvet S., Torres, A. G. (2010) Airborne particulate matter from livestock production systems: A review of an air pollution problem. Environmental Pollution, 158(1), pp. 1-17

Defra (2018) Agriculture in the United Kingdom 2017 Crown Copyright 2018 https://www.gov.uk/government/statistics/agriculture-in-the-united-kingdom-2017 (accessed 25/06/19)

Defra (2012) UK and EU Air Quality Limits (National Air Quality Objectives). https://ukair.defra.gov.uk/assets/documents/National_air_quality_objectives.pdf (accessed 25/6/16)

Defra (2009) Characterising poultry dust properties, assessing the human health implications, quantifying emission levels and assessing the potential for abatement, London. http://sciencesearch.defra.gov.uk/Default.aspx?Menu=Menu\&Module=More\&Location=None \&Completed $=0 \&$ Project $\mid \mathrm{D}=14432$ (accessed 30/10/18)

Douglas P., Robertson S., Gay R., Hansell A.L., Gant T.W. (2018) A systematic review of the public health risks from intensive farming. Int Jnl Hygiene and Env Health 221:134-173

Drew G., Deacon L., Pankhurst L., Pollard S. J., Tyrrel S. (2004) Guidance on the evaluation of bioaerosol risk assessments for composting facilities. Published by The Environment Agency.

Environmental Permitting Regulations (2010) The Environmental Permitting (England and Wales) Regulations 2010. http://www.legislation.gov.uk/ukdsi/2010/9780111491423/contents (accessed 30/10/18)

Environment Agency (2017) M9: Environmental monitoring of bioaerosols at regulated facilities. https://www.gov.uk/government/publications/m9-environmental-monitoring-of-bioaerosols-atregulated-facilities (accessed 30/10/18)

Gladding T.L., Gwyther C.L. (2017) A Study of the Potential Release of Bioaerosols from Containers as a Result of Reduced Frequency Residual Waste Collection. Science of the Total Environment. 576: 481-489

Gibbs S. G., Green C. F., Tarwater P. M., Mota L. C., Mena K. D., Scarpino P. V. (2006) Isolation of antibiotic-resistant bacteria from the air plume downwind of a swine confined or concentrated animal feeding operation. Environmental Health Perspectives, 114(7), pp. 1032-1037 
402 Gutarowska B., Skora J., Stepien L., Szponar B., Otlewska A., Pielech-Przybylska K. (2015) Assessment of microbial contamination within working environments of different types of composting plants. Journal of the Air \& Waste Management Association, 65(4), pp. 466-478

Hayes E. T., Curran T. P., Dodd, V. A. (2006) Odour and ammonia emissions from intensive pig units in Ireland. Bioresource Technology, 97(7), pp. 940-948

407 Health Council of the Netherlands (2010) Endotoxins. Health-based recommended occupational exposure limit, Publication no. 2010/04OSH.

Health Council of the Netherlands (2012) Health risks associated with livestock farms. 2012/27E., The Hague.

van der Hoek W., Dijkstra F., Schimmer B., Schneeberger P. M., Vellema P., Wijkmans C., ter Schegget R., Hackert V., van Duynhoven, Y. (2010) Q fever in the Netherlands: an update on the epidemiology and control measures. Eurosurveillance, 15(12), pp. 2007-2011

Jahne M. A., Rogers S. W., Holsen T. M., Grimberg S. J., Ramler, I. P. (2015) Emission and Dispersion of Bioaerosols from Dairy Manure Application Sites: Human Health Risk Assessment. Environmental Science \& Technology, p. 150730083724002.

Ko G., lii O. D. S., Likirdopulos C., Worley-davis, L., Williams, M., Sobsey, M. D. (2008) Investigation of Bioaerosols Released from Swine Farms using Conventional and Alternative Waste Treatment and Management Technologies. Environmental Science \& Technology, 42(23), pp. 8849-8857

Macher J. M. (1989) Positive-hole correction of multiple-jet impactors for collecting viable microorganisms. American Industrial Hygiene Association journal, 50(11), pp. 561-568

Masclaux F.G., Sakwinska O., Charrière N., Semaani E., Oppliger A., (2013) Concentration of airborne Staphylococcus aureus (MRSA and MSSA), total bacteria, and endotoxins in pig farms. Ann Occup Hyg. 57(5):550-7

O'Connor A. M., Auvermann B., Bickett-Weddle D., Kirkhorn S., Sargeant J. M., Ramirez A., Von Essen S. G. (2010) The association between proximity to animal feeding operations and community health: A systematic review. PLOS ONE, 5(3)

O'Gorman C. M. (2011). Airborne Aspergillus fumigatus conidia: a risk factor for aspergillosis. Fungal Biology Reviews, 25(3), pp. 151-157

Radon K., Schulze A., Ehrenstein V., van Strien R. T., Praml G., Nowak, D. (2007) Environmental exposure to confined animal feeding operations and respiratory health of neighboring residents. Epidemiology (Cambridge, Mass.), 18(3), pp. 300-308

R Core Team (2016). R: A language and environment for statistical computing. R Foundation for Stati stical Computing, Vienna, Austria. URL https://www.R-project.org/. 
Rylander R. (1997) Airborne (1-3)-beta-D-glucan and airway disease in a day-care center before and after renovation. Archives of microbiology, 52(4), pp. 281-285

Schinasi L., Horton R. A., Guidry V. T., Wing S., Marshall S. W., Morland K. B. (2011) Air pollution, lung function, and physical symptoms in communities near concentrated Swine feeding operations. Epidemiology (Cambridge, Mass.), 22(2), pp. 208-215.

Schulz J., Formosa L., Seedorf J., Hartung, J. (2011) Measurement of culturable airborne staphylococci downwind from a naturally ventilated broiler house. Aerobiologia, 27(4), pp. 311-318

Schulz J., Friese A., Klees S., Tenhagen B., Fetsch A., Rösler U., Hartung, J. (2012) Longitudinal study of the contamination of air and of soil surfaces in the vicinity of pig barns by livestock-associated methicillin-resistant Staphylococcus aureus. Applied and Environmental Microbiology, 78(16), pp. 5666-5671

Schulze A., Van Strien R., Ehrenstein V., Schierl R., Küchenhoff H., Radon K. (2006) Ambient endotoxin level in an area with intensive livestock production. Annals of Agricultural and Environmental Medicine, 13(1), pp. 87-91

Searl A. (2008). Exposure-response relationships for bioaerosol emissions from waste treatment processes, Institute of Occupational Medicine, Edinburgh, UK. http://sciencesearch.defra.gov.uk/Default.aspx?Menu=Menu\&Module=More\&Location=None \&Completed=0\&ProjectID=15140 (Accessed: 30/10/18)

Seiffert S. N, Hilty M, Perreten V., Endimiani A (2013) Extended-spectrum cephalosporin-resistant Gram-negative organisms in livestock: an emerging problem for human health? Drug Resistance Updates Feb-April; 16 (1-2), $22-45$

Smit, L.A., van der Sman-de Beer, F., Opstal-van Winden, A.W., Hooiveld, M., Beekhuizen, J., Wouters, I.M., Yzermans J., Heederik D., 2012. Q fever and pneumonia in an area with a high livestock density: a large population-based study. PLoS One 7, e38843.

Smit, L.A., Hooiveld, M., van der Sman-de Beer, F., Opstal-van Winden, A.W., Beekhuizen, J., Wouters, I.M., (2014) Air pollution from livestock farms, and asthma, allergic rhinitis and COPD among neighbouring residents. Occup. Environ. Med. 71, 134-140

Swan J. R. M., Kelsey A., Crook B. and Gilbert E. J. (2003). Occupational and environmental exposure to bioaerosols from composts and potential health effect - a critical review of published data. Sudbury, UK. http://www.hse.gov.uk/research/rrpdf/rr130.pdf (accessed 30/10/18)

Thorne P. S., Ansley A. C., Perry S. S. (2009) Concentrations of bioaerosols, odors, and hydrogen sulfide inside and downwind from two types of swine livestock operations. Journal of occupational and environmental hygiene, 6(4), pp. 211-220

Tilman D., Cassman K. G., Matson P., Naylor R., Polasky, S. (2002) Agricultural sustainability and intensive production practices. Nature, 418(6898), pp. 671-677 
Wallensten A., Moore P., Webster H., Johnson C., van der Burgt G., Pritchard G., Ellis-Iversen J., Oliver I. (2010) Q fever outbreak in Cheltenham, United Kingdom, in 2007 and the use of dispersion modelling to investigate the possibility of airborne spread. Eurosurveillance, 15(12)

\section{Acknowledgements}

The views expressed in this paper are those of the authors, and not necessarily those of the Environment Agency.

Funding: This work was funded by the Environment Agency for England and Wales grant numbers SC130025/1 and SC130025/2.

The authors declare no competing interests. 